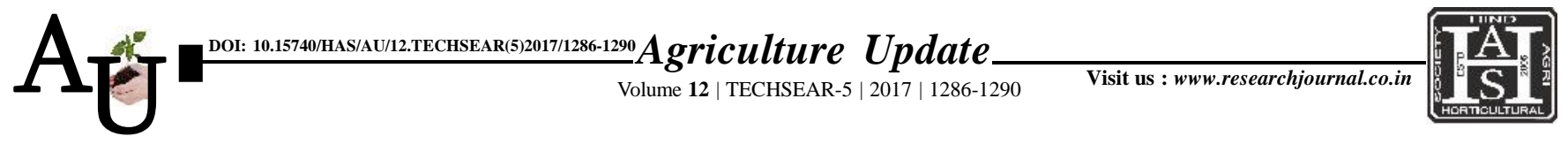

\title{
Research Article: Effect of soil test based nutrient management approaches on grain yield and nutrient uptake of dry DSR-mustard cropping system
}

\author{
RAGHAVENDRA, K. NARAYANA RAO, S.P. WANI, M.V. RAVI, H. VEERESH, \\ A.S. CHANNABASAVANNA AND MAHADEVA SWAMY
}

Article Chronicle:

Received :

15.07.2017;

Accepted :

30.07.2017

KeY WoRDS :

Dry direct seeded

rice, Mustard,

Nutrient uptake,

Targeted yield

approach, Soil test, Yield
SUMMARY : The improvement in grain yield characters was the manifestation of improved growth characters as a result of higher uptake of nutrients caused by balanced supply of nutrients in this regard soil test based nutrient management approaches aims provide a scientific basis for balanced fertilization to obtain more yield per unit of fertilizer investment. An experiment was conducted during Kharif and Rabi seasons of 2015-16 and 2016-17in the farmer field of Vijayanagar camp, Tq/Dist: Raichur, to study the effect soil test based nutrient management approacheson grain yield and nutrient uptake pattern in Dry DSR and their residual response was ascertained to mustard in DSR-mustard cropping sequence. Pooled results indicate that maximum rice yield $\left(54.73 \mathrm{q} \mathrm{ha}^{-1}\right)$ was recorded with application of nutrients as per SSNM approach for targeted yield of $55 \mathrm{q} \mathrm{ha}^{-1}$ in Dry DSR.Similarly maximum mustard seed yield $\left(592 \mathrm{~kg} \mathrm{ha}^{-1}\right)$ was recorded with the residual effect of nutrients through SSNM approach targeted yield of $55 \mathrm{q} \mathrm{ha}^{-1}$ and higher uptake of nutrients (grain + straw) viz., nitrogen $\left(117.72 \mathrm{~kg} \mathrm{ha}^{-1}\right)$, phosphorus ( $\left.40.50 \mathrm{~kg} \mathrm{ha}^{-1}\right)$ and potassium $\left(151.93 \mathrm{~kg} \mathrm{ha}^{-1}\right)$ by Dry DSR. Similarly higher uptake of nutrients (seed + stover) viz., nitrogen $\left(26.07 \mathrm{~kg} \mathrm{ha}^{-1}\right)$, phosphorus $\left(5.70 \mathrm{~kg} \mathrm{ha}^{-1}\right)$, and potassium $\left(34.99 \mathrm{~kg} \mathrm{ha}^{-1}\right)$ by mustardwas recorded with residual effect of nutrients through SSNM approach targeted yield of $55 \mathrm{q} \mathrm{ha}^{-1}$ as compared to RDF, farmer practice and other soil test methods.

How to cite this article : Raghavendra, Rao, K. Narayana, Wani, S.P., Ravi, M.V., Veeresh, H., Channabasavanna, A.S. and Swamy, Mahadeva (2017). Effect of soil test based nutrient management approaches on grain yield and nutrient uptake of dry DSR-mustard cropping system. Agric. Update, 12(TECHSEAR-5) : 1286-1290; DOI: 10.15740/HAS/AU/12.TECHSEAR(5)2017/1286-1290.
Author for correspondence :

\section{RAGHAVENDRA}

Department of Soil

Science and Agricultural

Chemistry, University of

Agricultural Sciences,

RAICHUR (KARNATAKA)

INDIA

See end of the article for

authors' affiliations 